Structural diversity in the borohydrido lanthanides series: first isolation and X Ray crystal structure of ionic $\left[\mathrm{Sm}\left(\mathrm{BH}_{4}\right)_{2}(\mathrm{THF})_{5}\right]^{+}\left[\mathrm{Cp}{ }^{* '} \mathrm{Sm}\left(\mathrm{BH}_{4}\right)_{3}\right]^{-}$.

Fanny Bonnet, ${ }^{\text {a }}$ Marc Visseaux *, ${ }^{\text {b }}$ Abderrafia Hafid, ${ }^{a}$ Denise Baudry-Barbier, ${ }^{a}$ Marek M. Kubicki, ${ }^{a \pi}$ Estelle Vigier. ${ }^{\text {ađ }}$

\title{
Graphical abstracts
}

Two new borohydrido complexes of samarium were prepared: $\left[\mathrm{Sm}\left(\mathrm{BH}_{4}\right)_{2}(\mathrm{THF})_{5}\right]^{+}\left[\mathrm{Cp}^{* \prime} \mathrm{Sm}\left(\mathrm{BH}_{4}\right)_{3}\right]^{-}(\mathbf{1})$ and $\mathrm{Cp}^{*{ }_{2}}{ }_{2} \mathrm{Sm}\left(\mathrm{BH}_{4}\right)(\mathrm{THF})(\mathbf{3})\left(\mathrm{Cp}^{*}{ }^{\prime}=\mathrm{C}_{5} \mathrm{Me}_{4}{ }^{n} \mathrm{Pr}\right) . \mathrm{X}$ Ray studies revealed that $\mathbf{1}$ displays an unprecedented ionic structure comprising a half samarocene moiety, whereas 3 is monomeric and bears a terminal $\mathrm{BH}_{4}$ ligand.
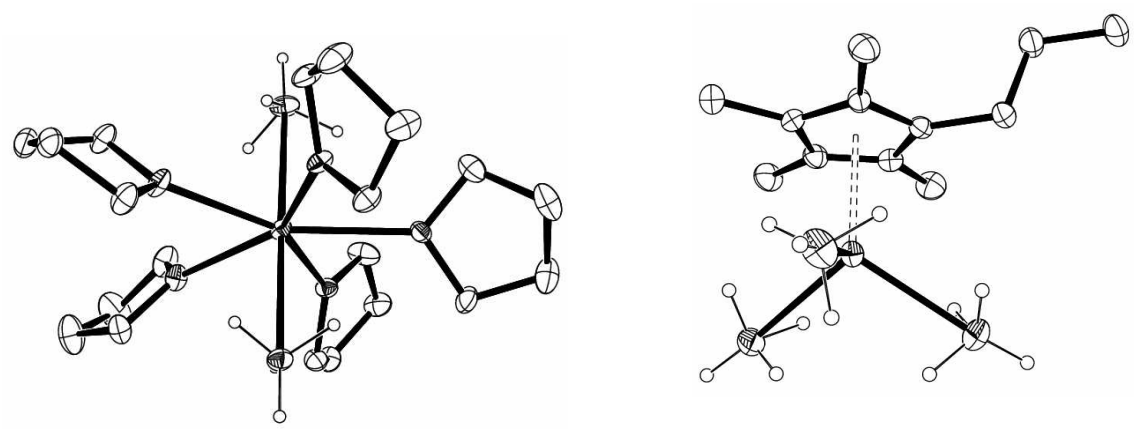


\title{
Structural diversity in the borohydrido lanthanides series: first isolation and X Ray crystal structure of ionic $\left[\mathrm{Sm}\left(\mathrm{BH}_{4}\right)_{2}(\mathrm{THF})_{5}\right]^{+}\left[\mathrm{Cp}{ }^{* '} \mathrm{Sm}\left(\mathrm{BH}_{4}\right)_{3}\right]^{-}$.
}

\author{
Fanny Bonnet, ${ }^{\text {a }}$ Marc Visseaux*, ${ }^{\text {b }}$ Abderrafia Hafid, ${ }^{a}$ Denise Baudry-Barbier, ${ }^{\text {a }}$ Marek \\ M. Kubicki, ${ }^{a \pi}$ Estelle Vigier. ${ }^{\text {aq }}$
}

${ }^{\mathrm{a}}$ Laboratoire de Synthèse et d'Electrosynthèse Organométalliques (LSEO), UMR 5188CNRS, Faculté des Sciences "Mirande", 9, av. Alain Savary, 21078 Dijon Cédex, France. " LSEO Structure and Modelization group.

${ }^{\text {b} U n i t e ́ ~ d e ~ C a t a l y s e ~ e t ~ C h i m i e ~ d u ~ S o l i d e ~(U C C S), ~ U M R ~ 8181-C N R S, ~ E N S C L, ~} 59655$ Villeneuve d'Ascq Cédex, France.

fax (+33) 320436585, e-mail : Marc.Visseaux@ensc-lille.fr

Keywords: samarium, borohydride, early lanthanides, monocyclopentadienyl

\begin{abstract}
.
The reaction of $\mathrm{Sm}\left(\mathrm{BH}_{4}\right)_{3}(\mathrm{THF})_{3}$ with a half equivalent of $\mathrm{KCp}^{* \prime}\left(\mathrm{Cp}^{* \prime}=\mathrm{C}_{5} \mathrm{Me}_{4}{ }^{n} \mathrm{Pr}\right)$ affords a compound comprising one $\mathrm{Cp}^{*}$ ' ligand and three THF molecules per two $\mathrm{Sm}$ atoms, [Cp*'Sm $\left.{ }_{2}\left(\mathrm{BH}_{4}\right)_{5}(\mathrm{THF})_{3}\right]$, according to analytical data. Crystals of the penta-THF adduct $\mathbf{1}$, showing the same ${ }^{1} \mathrm{H}$ NMR spectrum except for the quantity of THF, could be isolated from a solution of half-samarocene $\mathrm{Cp}^{*} \mathrm{Sm}\left(\mathrm{BH}_{4}\right)_{2}(\mathrm{THF})$, 2. X Ray structure determination of $\mathbf{1}$ revealed an ionic compound $\left[\mathrm{Sm}\left(\mathrm{BH}_{4}\right)_{2}(\mathrm{THF})_{5}\right]^{+}\left[\mathrm{Cp}{ }^{*} \mathrm{Sm}\left(\mathrm{BH}_{4}\right)_{3}\right]^{-}$with two discrete mononuclear $\mathrm{Sm}$ polyhedrons. The expected neutral samarocene $\mathrm{Cp}^{*}{ }_{2} \mathrm{Sm}\left(\mathrm{BH}_{4}\right)(\mathrm{THF})(3)$ could be obtained from the reaction of $\mathrm{Sm}\left(\mathrm{BH}_{4}\right)_{3}(\mathrm{THF})_{3}$ with two equivalents of $\mathrm{KCp}^{*}$. $\mathrm{X}$ Ray structure analysis showed that $\mathbf{3}$ is a monomeric complex bearing a terminal borohydride ligand. All $\mathrm{BH}_{4}{ }^{-}$ligands in $\mathbf{1}$ and $\mathbf{3}$ exhibit an $\eta^{3}-\mathrm{H}_{3} \mathrm{BH}$ bonding mode.
\end{abstract}


Since the last decade, an impressive number of reports have been devoted to polymerisation catalysis with lanthanide-based catalysts, and particularly in the fields concerning olefins [1, 2], conjugated dienes and styrene [3]. Recently, we described the syntheses of (very) uncommon examples of early half-lanthanidocenes, $\mathrm{Cp}{ }^{*} \operatorname{Ln}\left(\mathrm{BH}_{4}\right)_{2}(\mathrm{THF})_{\mathrm{n}}$ $\left(\mathrm{Cp}^{* \prime}=\mathrm{C}_{5} \mathrm{Me}_{4}{ }^{n} \mathrm{Pr} ; \mathrm{Ln}=\mathrm{Nd}, \mathrm{n}=2 ; \mathrm{Ln}=\mathrm{Sm}, \mathrm{n}=1\right)$ and their use as precatalysts for trans-1,4stereospecific polymerisation of isoprene in combination with dialkylmagnesium reagents [4, 5]. These powerful precatalysts were structurally characterized as desolvated clusters, $\left[\mathrm{Cp}^{* \prime} \operatorname{Ln}\left(\mathrm{BH}_{4}\right)_{2}\right]_{6}$, from slow toluene crystallisation, whereas the crude compounds were identified as solvated materials.

In consideration of a high level of catalytic performance of these materials, it was of importance to understand the rules of the synthesis of such precatalysts, in order to achieve the mastering of their preparation. We studied at the NMR scale the displacement of the $\mathrm{BH}_{4}$ groups of the precursor $\mathrm{Sm}\left(\mathrm{BH}_{4}\right)_{3}(\mathrm{THF})_{3}$ by successive additions of aliquots of $\mathrm{KCp}{ }^{* 1}$. These experiments suggested that, whereas the reaction with 1 equiv. of the cyclopentadienyl reagent afforded the known $\mathrm{Cp}^{*}{ }^{\prime} \mathrm{Sm}\left(\mathrm{BH}_{4}\right)_{2}$ (THF) (2), a new compound was formed in $50 \%$ yield by using 0.5 equivalent of the reagent. This new compound could be isolated in the presence of five THF per Sm, as the ionic pair $\left[\mathrm{Sm}\left(\mathrm{BH}_{4}\right)_{2}(\mathrm{THF})_{5}\right]^{+}\left[\mathrm{Cp}{ }^{* \prime} \mathrm{Sm}\left(\mathrm{BH}_{4}\right)_{3}\right]^{-}$. The biscyclopentadienyl derivative $\mathrm{Cp}^{*}{ }_{2} \mathrm{Sm}\left(\mathrm{BH}_{4}\right)(\mathrm{THF})(3)$, was normally obtained after a total addition of two equivalents of $\mathrm{KCp}^{* \prime}$. In this communication we present the syntheses and the $\mathrm{X}$ ray crystal structures of the two new complexes $\mathbf{1}$ and $\mathbf{3}$ and we discuss the mechanism of their formation.

By treatment of $\mathrm{Sm}\left(\mathrm{BH}_{4}\right)_{3}(\mathrm{THF})_{3}$ [6] with 0.5 equivalent of $\mathrm{KCp}$ *' (Scheme 1, pathway i) in toluene, and after usual work up, an analytically pure monocyclopentadienyl bimetallic complex of overall formula $\left[\mathrm{Cp}^{*} \mathrm{Sm}_{2}\left(\mathrm{BH}_{4}\right)_{5}(\mathrm{THF})_{3}\right]$ was obtained (see supplementary data).

$$
\begin{aligned}
& \mathrm{Sm}\left(\mathrm{BH}_{4}\right)_{3}(\mathrm{THF})_{3}+1 / 2 \mathrm{KCp}{ }^{* \prime} \stackrel{\text { i: toluene }}{\longrightarrow} 1 / 2\left[\mathrm{Cp}^{* \prime} \mathrm{Sm}_{2}\left(\mathrm{BH}_{4}\right)_{5}(\mathrm{THF})_{3}\right] \\
& \underset{2}{\mathrm{Cp} p^{*} \mathrm{Sm}\left(\mathrm{BH}_{4}\right)_{2}(\mathrm{THF})} \underset{\substack{\text { partial } \\
\text { hydrolysis }}}{\stackrel{\text { ii: toluene }}{\longrightarrow}}\left\{\left[\mathrm{Sm}\left(\mathrm{BH}_{4}\right)_{2}(\mathrm{THF})_{5}\right]^{+}\left[\mathrm{Cp}{ }^{* \prime} \mathrm{Sm}\left(\mathrm{BH}_{4}\right)_{3}\right]^{\top}\right\}
\end{aligned}
$$

Scheme 1. Synthesis of the monocyclopentadienyl bimetallic complex 
${ }^{1} \mathrm{H}$ NMR analysis established the presence of one $\mathrm{Cp}^{*}$ ' for $5 \mathrm{BH}_{4}$ groups and $3 \mathrm{THF}$. The $\mathrm{BH}_{4}$ groups provided one unique signal which supports the hypothesis that in solution all $\mathrm{BH}_{4}$ groups are under a fast fluxional exchange on the NMR time scale [7]. Unfortunately, all attempts to get crystals suitable for $\mathrm{X}$ ray analysis by adding various quantities of THF in a pentane solution of the complex were unsuccessful. $\mathrm{X}$ ray quality crystals of a monocyclopentadienyl bimetallic compound were in fact obtained from a solution of $\mathrm{Cp}{ }^{*} \mathrm{Sm}\left(\mathrm{BH}_{4}\right)_{2}(\mathrm{THF}), 2$, after partial hydrolysis (Scheme 1, pathway ii). The ${ }^{1} \mathrm{H}$ NMR spectrum of a sample of these crystals was identical to this of the bimetallic compound obtained by ionic metathesis (pathway i), except that the THF signals integrated for 5 molecules. Their structure was established as the ionic pair trisborohydrido cyclopentadienyl samarate(III) of bisborohydrido pentatetrahydrofurane samarium(III) $\left[\mathrm{Sm}\left(\mathrm{BH}_{4}\right)_{2}(\mathrm{THF})_{5}\right]^{+}\left[\mathrm{Cp}^{*} \mathrm{Sm}\left(\mathrm{BH}_{4}\right)_{3}\right]^{-}, \mathbf{1}$.

In the presence of a $2 / 1 \mathrm{Cp}^{*}$ ' ligand $/ \mathrm{Sm}\left(\mathrm{BH}_{4}\right)_{3}(\mathrm{THF})_{3}$ ratio (Eq. 1) the expected borohydrido samarocene $\mathrm{Cp}^{*}{ }_{2} \mathrm{Sm}\left(\mathrm{BH}_{4}\right)(\mathrm{THF})(3)$ could be readily obtained (yield $68 \%$ ) (see supplementary data).

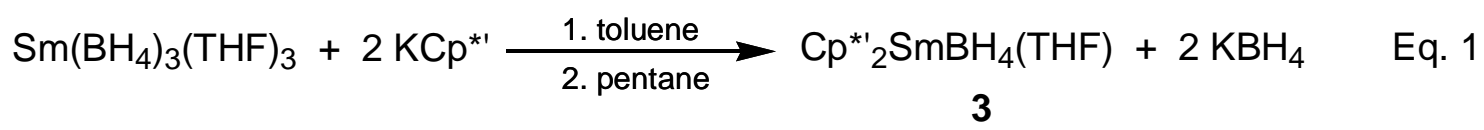

Its ${ }^{1} \mathrm{H}$ NMR spectrum was similar to that recorded in the preliminary experiment (see above [6]), except the quantity of THF which could be now unambiguously established as one molecule per Sm atom. The corresponding resonances $(\delta=-0.9$ and $-1.6 \mathrm{ppm})$ were found typical of $\left(\mathrm{Cp}^{\mathrm{R}}\right)_{2} \mathrm{SmX}(\mathrm{THF})$ samarocenes $\left(\mathrm{Cp}^{\mathrm{R}}\right.$ is a cyclopentadienyl ligand, $\left.\mathrm{X}=\mathrm{Cl}, \mathrm{BH}_{4}\right)[8$, 9], and show that the THF molecule remains coordinated to the paramagnetic center in solution, whereas the $\mathrm{BH}_{4}$ signal, as well as that of complex $\mathbf{1}$, appeared at high fields, in the usual range of chemical shifts for paramagnetic samarium complexes [4, 10]. After storage at room temperature of a pentane solution, a crop of orange bright crystals suitable for X Ray studies could be collected (see supplementary data).

(Table 1)

Crystallographic and refinement data of complexes $\mathbf{1}$ and $\mathbf{3}$ are gathered in Table 1. The compound $\mathbf{1}$ is an ion pair association of coordination $\mathrm{Sm}$ cation $\left[\mathrm{Sm}\left(\mathrm{BH}_{4}\right)_{2}(\mathrm{THF})_{5}\right]^{+}$and of organometallic Sm anion $\left[\mathrm{Cp}^{*} \mathrm{Sm}\left(\mathrm{BH}_{4}\right)_{3}\right]^{-}$(Figures 1a and $1 \mathrm{~b}$ ) that alternate in the orthorhombic (Pbca space group, $\mathrm{Z}=8$ ) unit cell without particular cation - anion interaction. 
The cations and the anions occupy the independent sets of general positions of Pbca group. The cation exhibits the pentagonal bipyramidal geometry (Figure 1) with two $\mathrm{BH}_{4}$ ligands placed in axial positions and with five oxygen atoms of THF molecules at the equatorial sites. The anion has a pseudo tetrahedral tri-legged piano-stool geometry (Figure 2). The Sm-B distances therein (six coordination) falling in a narrow range of 2.582(5) to 2.586(5) $\AA$ are slightly shorter than in the cation (seven coordination) where they are equal to $2.596(5)$ and $2.614(5) \AA$.

(Figure 1)

(Figure 2)

$\mathbf{1}$ is an ionic complex $\left[\mathrm{Sm}\left(\mathrm{BH}_{4}\right)_{2}(\mathrm{THF})_{5}\right]^{+}\left[\mathrm{Cp}{ }^{*} \mathrm{Sm}\left(\mathrm{BH}_{4}\right)_{3}\right]^{-}$containing discrete ions in the crystal lattice. A similar structure was published for an yttrium borohydride, $\left[\mathrm{Y}\left(\mathrm{BH}_{4}\right)_{2}(\mathrm{THF})_{4}\right]^{+}\left[\mathrm{Y}\left(\mathrm{BH}_{4}\right)_{3}\right]^{-}$where the $\mathrm{Y}$ atom is in a formal tetrahedral coordination (anion) with four $\mathrm{BH}_{4}$ groups or in octahedral coordination (cation) with two $\mathrm{BH}_{4}$ and four THF ligands. [11] Because of the smaller size of the yttrium atom than that of samarium, there are only four THF molecules in the coordination sphere of $\mathrm{Y}$ atom in the cation. A seven coordination in cationic $\left[\mathrm{LnX}_{2}(\mathrm{THF})_{5}\right]^{+}$species with trans - pentagonal bipyramidal geometry has been already found in some lanthanide ionic complexes [12-17]. The pseudotetrahedral tri-legged piano-stool geometry of the anion $\left[\mathrm{Cp}^{*} \mathrm{Sm}\left(\mathrm{BH}_{4}\right)_{3}\right]^{-}$in $\mathbf{1}$ (Figure 1b) is not common. A few precedent structures of this type have been reported in the lanthanides series [18-22]. The Sm-B distances in the cation (2.59(6) and 2.61(3) $\AA$ ) and in the anion (2.58(6) and 2.58(2) $\AA)$ of $\mathbf{1}$, as well as IR data, are compatible with a tridentate $\mathrm{Sm}-\left(\eta^{3}-\mathrm{H}\right)_{3} \mathrm{~B}-$ $\mathrm{H}$ mode of bonding, likely distorted however, as already observed [23, 24]. A borohydride anionic compound of trivalent uranium, showing very similar distances and angles, was also described. [25] The formal stoichiometry of 1 is $\mathrm{Cp}^{*}{ }^{\prime} \mathrm{Sm}_{2} \mathrm{X}_{5}(\mathrm{THF})_{5}\left(\mathrm{X}=\mathrm{BH}_{4}\right)$. To our knowledge, the same overall stoichiometry has been reported only on one occasion, for the $\mathrm{Sm}(\mathrm{III})$ complex with $\mathrm{X}=\mathrm{Cl}$ : $\left[\mathrm{Cp}(\mathrm{THF})_{2} \mathrm{SmCl} \mathrm{Cl}_{2} \mathrm{SmCl}_{2}(\mathrm{THF})_{3}\right]$ but the structure of this last complex is different. [26] Because of the presence therein of a less sterically demanding cyclopentadienyl ( $\left.\mathrm{Cp} v s . \mathrm{Cp}{ }^{*}\right)$ and of the chlorides $\left(v s . \mathrm{BH}_{4}\right)$, a molecular dinuclear structure results for, with THF molecules distributed over both metals and with two chloride bridges.

Mononuclear $\mathrm{Cp}^{*}{ }_{2} \mathrm{Sm}\left(\mathrm{BH}_{4}\right)(\mathrm{THF}), 3$ crystallizes in triclinic $\mathrm{P}-1$ space group with one molecule in the asymmetric unit. The molecular structure of $\mathbf{3}$ is typical of bent metallocenes. 
The $\mathrm{O}(\mathrm{THF})$ and $\mathrm{B}\left(\mathrm{BH}_{4}\right)$ atoms are located in the plane bisecting that of CNT1-Sm-CNT2 (CNT are the centroids of $\mathrm{C}_{5}$ rings). The $\mathrm{Sm}$ atom in $\mathbf{3}$ has a pseudo-tetrahedral geometry with eight-coordinated metal (Figure 3). The hydrogen atoms of $\mathrm{BH}_{4}$ could be located from difference Fourier map. The borohydride ligand is bound to the metal in a typical $\eta^{3}$-mode with B-H, Sm-H and B-H-Sm parameters falling in the ranges of 1.12(4) to 1.19(4) $\AA, 2.40(4)$ to $2.50(4) \AA$ and $66(2)$ to $71(2)^{\circ}$, respectively. It is noteworthy that the Sm-B distance (2.62(2) $\AA$ ) is typical of monomeric borohydrido samarocenes bearing a tridentate terminal $\mathrm{BH}_{4}$ group $[10,27]$. The $\mathrm{Cp}^{*}$ analogue of $3, \mathrm{Cp}^{*}{ }_{2} \mathrm{Sm}\left(\mathrm{BH}_{4}\right)(\mathrm{THF})$, synthesized differently in two steps, i.e. by salt metathesis starting from $\mathrm{LnCl}_{3}$ or its THF adduct, followed by the subsequent substitution of the last chloride by a borohydride, displays a very similar structure [9]. However, the hydrogen atoms of the tetrahydroborate ligand could not be located in this last case, thus preventing an exact description of the inner coordination sphere of the central samarium atom. The molecular structure of $\mathbf{3}$ (molecular shape and metric parameters) is closely related to those of $\mathrm{Cp}_{2}{ }_{2} \mathrm{Nd}\left(\mathrm{BH}_{4}\right)(\mathrm{THF})$ [23] and of $\left(\mathrm{C}_{5} \mathrm{Me}_{4} \mathrm{Et}\right)_{2} \mathrm{Y}\left(\mathrm{BH}_{4}\right)(\mathrm{THF})$ [9]. The $\mathrm{Cp}^{*}$ ' ligand is neither bulky nor electron-rich enough to allow, like in the case of $\mathrm{C}_{5} \mathrm{H}^{i} \mathrm{Pr}_{4}$, the isolation of a non solvated compound [10, 28]. With a less bulky di-substituted Cp ring [29], or a diketiminate (NRCR') ${ }_{2} \mathrm{CH}$ [30], a dimeric structure is observed, whereas an anionic 'ate' complex, $\left(\operatorname{tmp}_{2} \mathrm{Ln}\left(\mathrm{BH}_{4}\right)_{2}{ }^{-}(\mathrm{tmp}=\right.$ tetramethylphospholyl) was isolated in the electronic deficient phospholyl series [31].

(Figure 3)

In the treatment of $\mathrm{Sm}\left(\mathrm{BH}_{4}\right)_{3}(\mathrm{THF})_{3}$ with 0.5 equivalent of $\mathrm{KCp}^{* \prime}$, we expected the formation of $50 \%$ of $\mathrm{Cp}{ }^{*} \mathrm{Sm}\left(\mathrm{BH}_{4}\right)_{2}$ (THF) (2) in company with unreacted $\mathrm{Sm}\left(\mathrm{BH}_{4}\right)_{3}(\mathrm{THF})_{3}$. However, according to the ${ }^{1} \mathrm{H}$ NMR spectrum, it was clear than the result was not a $1: 1$ mixture of these two complexes. Due to the well-known exchange ability of the $\mathrm{BH}_{4}$ groups $[7,32]$, the observation of a single borohydride signal in the NMR spectrum was not surprising, but the new set of signals of the $\mathrm{Cp}^{* \prime}$ group denoted the presence of a different, plausibly bimetallic, compound: $\left[\mathrm{Cp}^{*} \mathrm{Sm}_{2}\left(\mathrm{BH}_{4}\right)_{5}(\mathrm{THF})_{\mathrm{n}}\right]$. In order to check the formation of such a dinuclear compound by direct comproportionation, an experiment consisting of the mixing of equal quantities of the neutral 2 and of $\operatorname{Sm}\left(\mathrm{BH}_{4}\right)_{3}(\mathrm{THF})_{3}$, at the NMR scale in $\mathrm{C}_{6} \mathrm{D}_{6}$, has been carried out (Eq. 2). The ${ }^{1} \mathrm{H}$ spectrum recorded immediately was the same as that obtained previously for $\mathbf{1}$. 


$$
\mathrm{Cp}^{*} \mathrm{Sm}\left(\mathrm{BH}_{4}\right)_{2}(\mathrm{THF})+\mathrm{Sm}\left(\mathrm{BH}_{4}\right)_{3}(\mathrm{THF})_{3} \longrightarrow\left[\mathrm{Cp}^{* \prime} \mathrm{Sm}_{2}\left(\mathrm{BH}_{4}\right)_{5}(\mathrm{THF})_{4}\right] \quad \text { Eq. } 2
$$

This clearly indicates that the bimetallic compound results from the reaction of a halfsamarocene, in particular obtained by ionic metathesis with $\mathrm{KCp} *$, with $\operatorname{Sm}\left(\mathrm{BH}_{4}\right)_{3}(\mathrm{THF})_{3}$. The ionic nature of complex $\mathbf{1}$ is quite surprising in view of the well-known covalency and neutral character of borohydrido complexes of lanthanides [33]. 1 probably results from ligands exchange (Eq. 3), followed by the formation of the ionic pair (Eq. 4).

$$
\begin{array}{ll}
{\left[\mathrm{Cp}^{\star \prime} \mathrm{Sm}_{2}\left(\mathrm{BH}_{4}\right)_{5}(\mathrm{THF})_{4}\right] \longrightarrow\left[\mathrm{Sm}\left(\mathrm{BH}_{4}\right)_{2}(\mathrm{THF})_{4} \mathrm{Cp} p^{* \prime} \mathrm{Sm}\left(\mathrm{BH}_{4}\right)_{3}\right]} & \text { Eq. } 3 \\
{\left[\mathrm{Sm}\left(\mathrm{BH}_{4}\right)_{2}(\mathrm{THF})_{4} \mathrm{Cp}^{\star \prime} \mathrm{Sm}\left(\mathrm{BH}_{4}\right)_{3}\right] \stackrel{\mathrm{THF}}{\longrightarrow}\left[\mathrm{Sm}\left(\mathrm{BH}_{4}\right)_{2}(\mathrm{THF})_{5}\right]^{+}\left[\mathrm{Cp}^{\star \prime} \mathrm{Sm}\left(\mathrm{BH}_{4}\right)_{3}\right]^{-}} & \text {Eq. } 4
\end{array}
$$

To our knowledge, the sole homologue of $\mathbf{1}, \mathrm{CpSmCl}(\mathrm{THF})_{2}(\mu-\mathrm{Cl})_{2} \mathrm{SmCl}_{2}(\mathrm{THF})_{3}$, is a covalent compound. However, one can not affirm that $\mathbf{1}$ does not exist under a neutral form in solution, undergoing reversible auto-ionization to give rise to the ionic pair [34]. This would be in agreement with i) the good solubility of this compound in aromatic solvents and ii) the observation of a single average $\mathrm{BH}_{4}{ }^{1} \mathrm{H}$ NMR signal. The formation of the ionic compound 1 would occur only in the presence of the required quantities of THF. Less soluble, it would then crystallize. Similar auto-ionizations were reported; they are always observed in THF [15, $35,36]$. However, their origin has never been discussed. The driving force of such process would probably be the concomitant formation of two stable lanthanide molecular species (see the above-mentioned references): a tetrahedral anionic monocyclopentadienyl one, and an heptacoordinated cationic one.

\section{Conclusion.}

The results presented in this paper are illustrative of the structural diversity in the lanthanides chemistry, and especially in the borohydride series. Metathetic reaction between $\mathrm{Sm}\left(\mathrm{BH}_{4}\right)_{3}(\mathrm{THF})_{3}$ as valuable precursor and $\mathrm{Cp}^{*} \mathrm{~K}$ yielded two new organolanthanide compounds bearing $1 / 2$ and $2 \mathrm{Cp}^{*}$, per $\mathrm{Sm}$ atom. With a sufficient amount of THF, the mononuclear ionic complex $\mathbf{1}$, containing discrete $\left[\mathrm{Sm}\left(\mathrm{BH}_{4}\right)_{2}(\mathrm{THF})_{5}\right]^{+}$cation and $\left[\mathrm{Cp}^{*} \mathrm{Sm}\left(\mathrm{BH}_{4}\right)_{3}\right]^{-}$anion was isolated. Stereo-electronic effects of the borohydride ligand strongly influence the ionic nature of $\mathbf{1}$ with respect to chloride in its chloro homologue, whereas they allow the isolation of a neutral monomeric structure for the samarocene 3 . 


\section{Supplementary material}

All experimental details for the syntheses of complexes $\mathbf{1}$ and $\mathbf{3}$, including preliminary ${ }^{1} \mathrm{H}$ NMR experiments. CCDC 603086 and 603087 contain the supplementary crystallographic data for $\mathbf{1}$ and $\mathbf{3}$, respectively.

\section{References.}

[1] J. Gromada, J. F. Carpentier, A. Mortreux, Coord. Chem. Rev. 248 (2004) 397.

[2] Y. Nakayama, H. Yasuda, J. Organomet. Chem. 689 (2004) 4489.

[3] Z. Hou, Y. Luo, X. Li, J. Organomet. Chem. in press (published online) (2006).

[4] F. Bonnet, M. Visseaux, A. Hafid, D. Barbier-Baudry, E. Vigier, M. M. Kubicki, Inorg. Chem. 43 (2004) 3682.

[5] F. Bonnet, M. Visseaux, A. Pereira, D. Barbier-Baudry, Macromolecules 38 (2005) 3162

[6] U. Mirsaidov, I. B. Shaimuradov, M. Khikmatov, Russ. J. Inorg. Chem. 5 (1986) 753.

[7] G. L. Soloveichik, New J. Chem. 19 (1995) 597.

[8] W. J. Evans, L. R. Chamberlain, T. A. Ulibarri, J. W. Ziller, J. Am. Chem. Soc. 110 (1988) 6423.

[9] H. Schumann, M. R. Keitsch, J. Demtschuk, S. H. Muhle, Z. Anorg. All. Chem. 624 (1998) 1811.

[10] D. Barbier-Baudry, O. Blacque, A. Hafid, A. Nyassi, H. Sitzmann, M. Visseaux, Eur. J. Inorg. Chem. (2000) 2333.

[11] E. B. Lobkovskii, S. E. Kravchenko, O. V. J. Kravchenko, Struct. Chem. (USSR) 23 (1982) 582.

[12] G. B. Deacon, T. Feng, P. C. Junk, B. W. Skelton, A. N. Sobolev, A. H. White, Australian J. Chem. 51 (1998) 75.

[13] G. R. Willey, T. J. Woodman, D. J. Carpenter, W. Errington, J. Chem. Soc., Dalton Trans. (1997) 2677.

[14] G. V. Khoroshen'kov, A. A. Fagin, M. N. Bochkarev, S. Deckert, H. Schumann, Russ. Chem. Bull. Int. Ed. 52 (2003) 1715.

[15] Z. Xie, K. Chiu, B. Wu, T. C. W. Mak, Inorg. Chem. 35 (1996) 5957.

[16] W. J. Evans, I. Bloom, J. W. Grate, L. A. Hugues, W. E. Hunter, J. L. Atwood, Inorg. Chem. 24 (1985) 4620. 
[17] W. J. Evans, J. M. Olofson, J. W. Ziller, J. Am. Chem. Soc. 112 (1990) 2308.

[18] H. Schumann, I. Albrecht, J. Pickardt, E. Hahn, J. Organomet. Chem. 276 (1984) C5.

[19] J. Guan, S. Jin, Y. Lin, Q. Shen, Organometallics 11 (1992) 2483.

[20] L. Mao, Q. Shen, S. Jin, Polyhedron 13 (1994) 1023.

[21] R. J. Butcher, D. L. Clark, J. C. Gordon, J. G. Watkin, J. Organomet. Chem. 577 (1999) 228.

[22] R. Taube, S. Maiwald, J. Sieler, J. Organomet. Chem. 513 (1996) 37.

[23] M. Visseaux, T. Chenal, A. Mortreux, P. Roussel, J. Organomet. Chem. 2006, 691, 86.

[24] C. T. Qian, G. Zou, W. Nie, J. Sun, D. A. Lemenovski, M. V. Borzov, Polyhedron 19 (2000) 1955.

[25] R. R. Ryan, K. V. Salazar, N. N. Sauer, J. M. Ritchey, Inorg. Chim. Act. 162 (1989) 221.

[26] G. Z. De Paoli, P.; Valle, G., Inorg. Chim. Acta 170 (1990) 109.

[27] H. Schumann, M. R. Keitsch, S. H. Muhle, Acta Cryst. C56 (2000) 48.

[28] M. Visseaux, D. Barbier-Baudry, O. Blacque, A. Hafid, P. Richard, F. Weber, New J. Chem. 24 (2000) 939.

[29] Y. K. Gun'ko, B. M. Bulyshev, G. L. Soloveichik, V. K. Belsky, J. Organomet. Chem. 424 (1992) 289.

[30] F. Bonnet, M. Visseaux, D. Barbier-Baudry, E. Vigier, M. M. Kubicki, Chem. Eur. J. 10 (2004) 2428.

[31] S. Cendrowski-Guillaume, G. Le Gland, M. Nierlich, M. Ephritikhine, Organometallics 19 (2000) 5654.

[32] M. Ephritikhine, Chem. Rev. 97 (1997) 2193.

[33] T. J. Marks, J. R. Kolb, Chem. Rev. 77 (1977) 263.

[34] Equilibria between discrete ionic alkyl species and non-ionic compounds are postulated in polymerization multicomponent catalytic mixtures. See S. Arndt, J. Okuda, Adv. Synth. Catal. 347 (2005) 339.

[35] W. J. Evans, J. L. Shreeve, J. W. Ziller, R. J. Doedens, Inorg. Chem. 34 (1995) 576.

[36] P. Sobota, J. Utko, S. Szafert, Inorg. Chem. 33 (1994) 5203. 
Table 1. Crystallographic data for complexes $\mathbf{1}$ and $\mathbf{3}$

\begin{tabular}{|c|c|c|}
\hline & 1 & 3 \\
\hline Colour & orange & red \\
\hline Shape & Irregular & Irregular \\
\hline Size $(\mathrm{mm})$ & $0.33 \times 0.25 \times 0.03$ & $0.30 \times 0.20 \times 0.10$ \\
\hline Chemical formula & $\mathrm{C}_{32} \mathrm{H}_{79} \mathrm{O}_{5} \mathrm{~B}_{5} \mathrm{Sm}_{2}$ & $\mathrm{C}_{28} \mathrm{H}_{50} \mathrm{BOSm}$ \\
\hline Formula weight & 898.74 & 563.84 \\
\hline Crystal system & Orthorhombic & Triclinic \\
\hline Space group & Pbca (61) & P-1 (2) \\
\hline $\mathrm{T}(\mathrm{K})$ & 120 & 110 \\
\hline a $(\AA)$ & $15.8765(2)$ & $8.592(5)$ \\
\hline $\mathrm{b}(\AA)$ & $16.6759(2)$ & $10.678(5)$ \\
\hline$c(\AA)$ & $33.4264(6)$ & $15.163(5)$ \\
\hline$\alpha\left(^{\circ}\right)$ & 90 & $91.355(5)$ \\
\hline$\beta\left(^{\circ}\right)$ & 90 & $102.833(5)$ \\
\hline$\gamma\left({ }^{\circ}\right)$ & 90 & $90.972(5)$ \\
\hline $\mathrm{V}\left(\AA^{3}\right)$ & $8849.8(2)$ & $1355.7(11)$ \\
\hline $\mathrm{Z}$ & 8 & 2 \\
\hline $\mathrm{D}_{\text {calc }}\left(\mathrm{g} \cdot \mathrm{cm}^{-3}\right)$ & 1.349 & 1.381 \\
\hline$\mu(\mathrm{MoK} \alpha),\left(\mathrm{Mm}^{-1}\right)$ & 2.659 & 2.182 \\
\hline$\dot{\lambda}(\mathrm{MoK} \alpha),(\AA)$ & 0.71073 & 0.71073 \\
\hline $\mathrm{F}(000)$ & 3680 & 586 \\
\hline$\theta$ range $\left(^{\circ}\right)$ & $1.018 ; 21.036$ & $2.32 ; 29.39$ \\
\hline hkl ranges $h$ & {$[0 ; 16]$} & {$[-11 ; 10]$} \\
\hline $\mathrm{k}$ & {$[0 ; 16]$} & {$[-14 ; 14]$} \\
\hline 1 & {$[0 ; 33]$} & {$[-18 ; 20]$} \\
\hline collected reflections & 8939 & 9324 \\
\hline unique reflections & 4729 & 6765 \\
\hline observed reflections & 3906 & 5190 \\
\hline$\left(\mathrm{R}_{\text {int }}\right)$ & 0.021 & 0.040 \\
\hline Parameters & 477 & 306 \\
\hline restraints & 0 & 0 \\
\hline $\begin{array}{l}\text { Goodness-of-fit on } \\
\mathrm{F}^{2}\end{array}$ & 1.043 & 0.987 \\
\hline $\begin{array}{l}\mathrm{R}(\mathrm{F}), \mathrm{R} w\left(\mathrm{~F}^{2}\right)^{a} \\
{[\mathrm{I}>2 \sigma(\mathrm{I})]}\end{array}$ & $0.0275,0.0598$ & $0.0438,0.0709$ \\
\hline $\begin{array}{l}\mathrm{R}(\mathrm{F}), \mathrm{R} w\left(\mathrm{~F}^{2}\right)^{a} \text { (all } \\
\text { data) }\end{array}$ & $0.0395,0.0643$ & $0.0737,0.0784$ \\
\hline$w^{b} / \mathrm{a}, \mathrm{b}$ & $0.0227,22.5500$ & $0.0232,0.000$ \\
\hline$\rho_{\max }, \rho_{\min }\left(\mathrm{e} . \AA^{-3}\right)$ & $1.288,-0.480$ & $1.223,-1.181$ \\
\hline
\end{tabular}

${ }^{a} R(F)=\Sigma|| \mathrm{F}_{\mathrm{o}}|-| \mathrm{F}_{\mathrm{c}}|/ \Sigma| \mathrm{F}_{\mathrm{o}} \mid ; \mathrm{R} w\left(F^{2}\right)=\left[\Sigma w\left(\mathrm{~F}_{\mathrm{o}}{ }^{2}-\mathrm{F}_{\mathrm{c}}{ }^{2}\right)^{2} / \Sigma\left[w\left(\mathrm{~F}_{\mathrm{o}}{ }^{2}\right)^{2}\right]^{1 / 2} \cdot{ }^{b} w=1 /\left[\sigma^{2}\left(\mathrm{~F}_{\mathrm{o}}{ }^{2}\right)+(\mathrm{a} P)^{2}+\mathrm{b} P\right]\right.$ with $P=\left(\mathrm{F}_{\mathrm{o}}^{2}+2 \mathrm{~F}_{\mathrm{c}}^{2}\right) / 3$ 


\section{Figures captions}

Figure 1. ORTEP drawing (30\% probability level) of the cationic molecule in 1. Selected bond distances ( $\AA$ ) and angles (deg): Sm2-B4 2.622(8), Sm2-B5 2.623(8), Sm2-O1 2.485(3), Sm2-O2 2.491(3), Sm2-O3 2.483(4), Sm2-O4 2.495(4), Sm2-O5 2.473(3), Sm2-Hb41 2.36(5), Sm2-Hb42 2.45(5), Sm2-Hb43 2.39(6), Sm2-Hb51 2.40(5), Sm2-Hb52 2.37(5), Sm2-Hb53 2.34(5), B4-Sm2-B5 176(6), sum of five O-Sm2-O neighbour angles 360.6.

Figure 2. ORTEP drawing (30\% probability level) of the anionic molecule in the structure of 1. Selected bond distances $(\AA)$ and angles (deg) (CP is the geometrical center of C1-C5 atoms): Sm1-CP 2.405, Sm1-B1 2.592(8), Sm1-B2 2.589(8), Sm1-B3 2.583(8), mean of nine $\mathrm{Sm} 1-\eta^{3} \mathrm{Hb} 2.41(6)$, mean of nine B- $\eta^{3} \mathrm{Hb} 1.11(6)$, mean of three B-Hb terminal 1.12(6), CPSm1-B1 114.3, CP-Sm1-B2 112.7, CP-Sm1-B3 116.4, mean of three Sm1-B-Hb terminal $175(4)$.

Figure 3. ORTEP drawing (30\% probability level) of metallocene 3. Selected bond distances ( $\AA)$ and angles (deg) (CP1 and CP2 are the geometrical centers of C1-C5 and C6-C10 rings, respectively): Sm - CP1 2.458, Sm - CP2 2.471, CP1 - Sm - CP2 133.65, Sm - B 2.621(5), $\mathrm{Sm}-\mathrm{O} 2.483(3), \mathrm{B}-\mathrm{Sm}-\mathrm{O}$ 87.7(1), mean of three Sm - H(bridging) 2.45(4), mean of three B - H(bridging) 1.14(5), B - H4b 1.15(4), Sm - B - H4b 171(2) 